\title{
Platelet Shape Change Abnormalities in Diabetic Retinopathy
}

\author{
M. Porta, P. Hilgard ${ }^{1}$, and E. M. Kohner \\ Departments of Medicine and ${ }^{1}$ Haematology, Hammersmith Hospital, London, England
}

\begin{abstract}
Summary. In vitro platelet aggregation has been studied in 29 normal subjects and 35 diabetic patients with retinopathy by conventional aggregating agents and by a new technique which evaluates the platelet shape change. - Platelet shape change, expressed as \% light transmission variation induced by the addition of ADP $(10 \mu \mathrm{mol} / \mathrm{l})$ in calcium-deprived platelet rich plasma, was determined. Significant differences were found between the controls $(12.6 \pm 0.7 \%)$ and the 35 diabetics $(15.6 \pm 1.0 \%$, p $<0.02)$ and between controls and the subgroup of patients with proliferative retinopathy $(17.3 \pm 1.1 \%$, $\mathrm{n}=15, \mathrm{p}<0.001$ ). Platelet aggregation induced by ADP, collagen and ristocetin did not show significant differences between normal and diabetic subjects. The shape change is the physiological early phase of platelet aggregation and is related to energy requiring mechanisms. As yet unexplored metabolic abnormalities at this stage could account for previously described platelet abnormalities in diabetes.
\end{abstract}

Key words: Diabetes, diabetic retinopathy, platelets, platelet aggregation, platelet shape change.

Increased platelet aggregability has been reported in diabetic patients $[1,2,3,4,5]$. It was suggested that abnormally reacting platelets play a significant role in the occlusion of small vessels, which is the most important clinical feature of diabetic retinopathy and possibly of all other manifestations of diabetic microangiopathy [6].

When platelets are stimulated by aggregating agents, such as adenosine disphosphate (ADP), collagen or thrombin, they lose their discoid shape, become spherical and extrude pseudopodia from their surface [7]. This phenomenon is known as "platelet shape change" (PSC) and represents the initial stage of platelet aggregation; unlike the following events, it does not require calcium ions $\left(\mathrm{Ca}^{++}\right)$.

As previous attempts to study platelet aggregation in vitro were concerned with the later stages of aggregation, it was decided to investigate PSC in matched controls and diabetics. PSC was evaluated by the modification in optical density induced in platelet rich plasma (PRP) by ADP, in the presence of a chelating agent. A parallel study on platelet aggregation was also carried out with conventional techniques.

\section{Patients and Methods}

\section{Platelet Shape Change}

Patients. Blood samples were obtained from 29 healthy controls and 35 diabetic patients. The diabetics were divided into 3 groups according to the severity of retinopathy: 11 had mild retinopathy, 9 had maculopathy and 15 had proliferative retinopathy. Sex, age, duration of disease, ponderal index, hypoglycaemic treatment and blood glucose measured on the morning of the study are shown in Table 1 for the different groups. None of the control subjects were on any drugs for 15 days prior to the investigation. Nine out of the 35 diabetics studied were on additional drugs ( $\alpha$-methyldopa and or thiazide diuretics), being equally distributed among the 3 subgroups. Informed consent was obtained from the patients at the time of venesection.

Diabetic Retinopathy Assessment. Diabetic retinopathy was assessed by one of us (E.M.K.) ophthalmoscopically and by colour photography of the fundi. Background retinopathy was defined as the presence of microaneurysms, retinal haemorrhages, hard exudates and cotton wool spots without macular oedema; maculopathy as background retinopathy with visual impairment due to macular oedema. Presence of new vessels and/or fibrous tissue indicated proliferative retinopathy. 
Table 1. Platelet shape change (PSC) evaluation in normal controls and in 3 different groups of diabetic patients

\begin{tabular}{|c|c|c|c|c|c|c|c|c|c|}
\hline Groups & $n$ & Sex & $\begin{array}{l}\text { Age in years: } \\
\text { mean and } \\
\text { (range) }\end{array}$ & $\begin{array}{l}\text { Duration of } \\
\text { disease in } \\
\text { years: } \\
\text { mean and } \\
\text { (range) }\end{array}$ & $\begin{array}{l}\text { Ponderal } \\
\text { index }\end{array}$ & $\begin{array}{l}\text { Hypoglycaemic } \\
\text { therapy }^{\mathrm{b}}\end{array}$ & $\begin{array}{l}\text { Blood } \\
\text { glucose } \\
(\mathrm{mmol} / \mathrm{l})^{\mathrm{c}}\end{array}$ & PSC & $\begin{array}{l}\text { Significance } \\
\text { (versus } \\
\text { controls) }\end{array}$ \\
\hline Controls & 29 & $\begin{array}{l}M=15 \\
F=14\end{array}$ & $\begin{array}{l}42 \\
(20-71)\end{array}$ & - & $\begin{array}{l}105.4 \\
\pm 1.7\end{array}$ & - & - & $12.6 \pm 0.7$ & - \\
\hline $\begin{array}{l}\text { Diabetics with } \\
\text { background } \\
\text { retinopathy }\end{array}$ & 11 & $\begin{array}{l}M=6 \\
F=5\end{array}$ & $\begin{array}{l}44 \\
(20-79)\end{array}$ & $\begin{array}{l}15 \\
(3-27)\end{array}$ & $\begin{array}{l}112.3 \\
\pm 4.1\end{array}$ & $\begin{array}{l}I=64 \% \\
O=27 \% \\
D=9 \%\end{array}$ & $\begin{array}{r}9.6 \\
\pm 1.1\end{array}$ & $\begin{array}{r}14.0 \\
\pm 1.5\end{array}$ & NS \\
\hline $\begin{array}{l}\text { Diabetics with } \\
\text { maculopathy }\end{array}$ & 9 & $\begin{array}{l}M=4 \\
F=5\end{array}$ & $\begin{array}{l}64 \\
(50-71)\end{array}$ & $\begin{array}{l}14 \\
(4-29)\end{array}$ & $\begin{array}{l}120.8 \\
\pm 5.0\end{array}$ & $\begin{array}{l}I=45 \% \\
O=33 \% \\
D=22 \%\end{array}$ & $\begin{array}{r}8.4 \\
\pm 0.9\end{array}$ & $\begin{array}{r}14.9 \\
\pm 0.9\end{array}$ & NS \\
\hline $\begin{array}{l}\text { Diabetics with } \\
\text { proliferative } \\
\text { retinopathy }\end{array}$ & 15 & $\begin{array}{l}M=11 \\
F=4\end{array}$ & $\begin{array}{l}51 \\
(25-66)\end{array}$ & $\begin{array}{l}17 \\
(1-42)\end{array}$ & $\begin{array}{l}119.9 \\
\pm 3.9\end{array}$ & $\begin{array}{l}I=74 \% \\
O=13 \% \\
D=13 \%\end{array}$ & $\begin{array}{r}8.6 \\
\pm 1.7\end{array}$ & $\begin{array}{r}17.3 \\
\pm 1.1\end{array}$ & p 0.001 \\
\hline
\end{tabular}

a Percent of desirable body weight, according to the middle of the weight range for subjects of medium frame, from the 1959 Metropolitan Life Insurance Co. Tables

${ }^{\mathrm{b}} \mathrm{I}=$ insulin treatment; $\mathrm{O}=$ oral agents; $\mathrm{D}=$ diet only

c Random blood glucose values on the morning of study

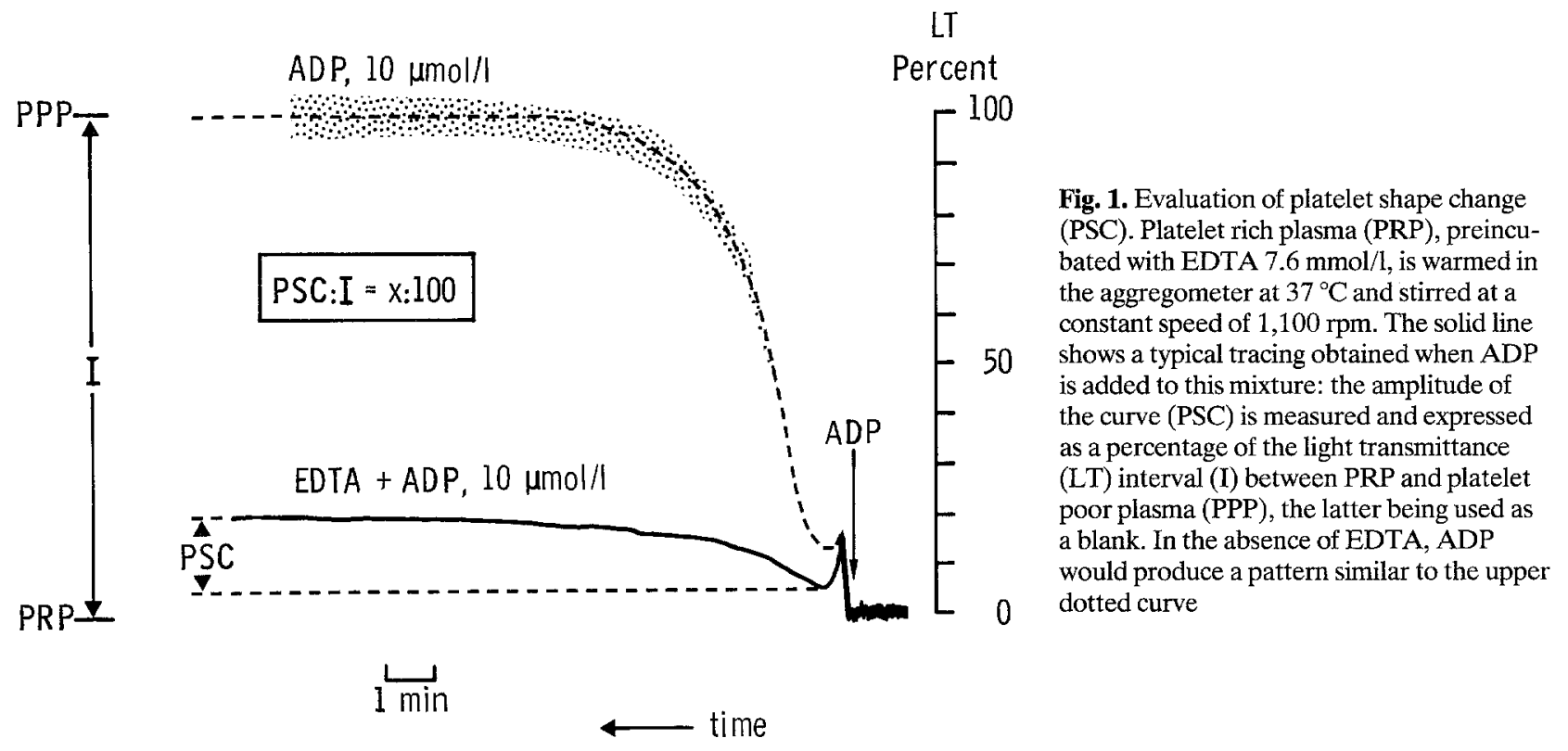

Methods. Blood was collected without stasis from an antecubital vein by a $19-\mathrm{G}(1.1 \mathrm{~mm})$ butterfly needle into a plastic syringe. Nine parts of blood were mixed with one part of $120 \mathrm{mmol} / \mathrm{l}$ trisodium citrate in plastic tubes. The samples were spun for $5 \mathrm{~min}$ at $140 \mathrm{~g}$, at room temperature, and the platelet rich plasma (PRP) was collected by a plastic automatic pipette into a plastic tube. The remainder was then spun for $15 \mathrm{~min}$ at $1,600 \mathrm{~g}$, at room temperature, for platelet poor plasma (PPP). A platelet count was performed on PRP by a Coulter Counter (Coulter El. Ltd., Harpenden, Herts.), and the concentration adjusted to $220,000-320,000$ platelets/ $\mu$ l with PPP.

Five $\mu$ l of ethylenediaminetetraacetate (EDTA) (BDH Chem., Poole, Dorset) were mixed with $500 \mu$ of PRP, giving a final con- centration of $7.6 \mathrm{mmol} / \mathrm{l}$. The mixture was inserted into an aggregometer ( $\mathrm{H}$. Upchurch \& Co. Ltd., Abbey Gate, Leicester) at $37^{\circ} \mathrm{C}$ and stirred by a magnetic bar $(1,100 \mathrm{rpm})$. PPP was taken as $100 \%$ and PRP as $0 \%$ of light transmittance (LT).

Fifty $\mu$ l of ADP (Sigma Chem. Corp., St. Louis, Missouri) solution (final concentration $10 \mu \mathrm{mol} / \mathrm{l}$ ) were added when no variations in light transmittance were recorded through PRP for at least 1 min. ADP produces a rapid decrease, followed by a slower increase in LT when added to $\mathrm{Ca}^{++}$-deprived PRP. This curve was taken as complete when a straight line was recorded for at least 1 min. After this point no further changes were ever recorded. The amplitude was measured and expressed as \% light transmittance (Fig. 1). PSC tracings were mainly influenced by variations of the 
Table 2. Conventional platelet aggregation studies - see Patients and Methods

\begin{tabular}{|c|c|c|c|c|c|c|c|c|c|c|}
\hline \multirow[b]{2}{*}{ Groups } & \multirow[b]{2}{*}{$\mathrm{n}^{\mathrm{a}}$} & \multirow[b]{2}{*}{ Sex } & \multirow[b]{2}{*}{$\begin{array}{l}\text { Age in years: } \\
\text { mean and } \\
\text { (range) }\end{array}$} & \multirow[b]{2}{*}{$\begin{array}{l}\text { Duration } \\
\text { of disease: } \\
\text { mean and } \\
\text { (range) }\end{array}$} & \multirow[b]{2}{*}{$\begin{array}{l}\text { Ponderal } \\
\text { index }\end{array}$} & \multirow[b]{2}{*}{$\begin{array}{l}\text { Antidiabetic } \\
\text { therapyc }^{c}\end{array}$} & \multirow[b]{2}{*}{$\begin{array}{l}\text { Blood } \\
\text { glucose } \\
(\mathrm{mmol} / \mathrm{l})\end{array}$} & \multicolumn{3}{|c|}{ Platelet aggregation } \\
\hline & & & & & & & & $\begin{array}{l}\text { ADP } 10 \\
\mu \mathrm{mol} / 1\end{array}$ & Collagen & Ristocetin \\
\hline Controls & $\begin{array}{c}17 \\
(12)\end{array}$ & $\begin{array}{l}M=9 \\
F=8\end{array}$ & $\begin{array}{l}40 \\
(20-71)\end{array}$ & - & $\begin{array}{l}107.0 \\
\pm 2.6\end{array}$ & - & - & $\begin{array}{l}81.4 \% \\
\pm 2.5\end{array}$ & $\begin{array}{l}66.8 \% \\
\pm 2.4\end{array}$ & $\begin{array}{l}85.6 \% \\
\pm 1.8\end{array}$ \\
\hline $\begin{array}{l}\text { Diabetics } \\
\text { with } \\
\text { background } \\
\text { retinopathy }\end{array}$ & $\begin{array}{r}10 \\
(9)\end{array}$ & $\begin{array}{l}M=6 \\
F=4\end{array}$ & $\begin{array}{l}43 \\
(20-79)\end{array}$ & $\begin{array}{l}15 \\
(3-27)\end{array}$ & $\begin{array}{l}112.3 \\
\pm 4.3\end{array}$ & $\begin{array}{l}I=60 \% \\
O=30 \% \\
D=10 \%\end{array}$ & $\begin{array}{r}9.2 \\
\pm 1.2\end{array}$ & $\begin{array}{l}75.6 \% \\
\pm 2.5\end{array}$ & $\begin{array}{l}62.9 \% \\
\pm 2.7\end{array}$ & $\begin{array}{l}84.9 \% \\
\pm 2.0\end{array}$ \\
\hline $\begin{array}{l}\text { Diabetics } \\
\text { with } \\
\text { maculopathy }\end{array}$ & $\begin{array}{c}10 \\
(2)\end{array}$ & $\begin{array}{l}M=5 \\
F=5\end{array}$ & $\begin{array}{l}58 \\
(25-66)\end{array}$ & $\begin{array}{l}18 \\
(5-27)\end{array}$ & $\begin{array}{r}119.5 \\
\pm 3.3\end{array}$ & $\begin{array}{l}I=70 \% \\
O=20 \% \\
D=10 \%\end{array}$ & $\begin{array}{r}9.0 \\
\pm 1.3\end{array}$ & $\begin{array}{l}79.5 \% \\
\pm 3.5\end{array}$ & $\begin{array}{l}64.7 \% \\
\pm 6.4\end{array}$ & $\begin{array}{l}87.8 \% \\
\pm 5.5\end{array}$ \\
\hline $\begin{array}{l}\text { Diabetics } \\
\text { with } \\
\text { proliferative } \\
\text { retinopathy }\end{array}$ & $\begin{array}{l}10 \\
(6)\end{array}$ & $\begin{array}{l}M=6 \\
F=4\end{array}$ & $\begin{array}{l}50 \\
(24-66)\end{array}$ & $\begin{array}{l}17 \\
(1-42)\end{array}$ & $\begin{array}{l}118.1 \\
\pm 6.0\end{array}$ & $\begin{array}{l}I=80 \% \\
D=20 \%\end{array}$ & $\begin{array}{r}9.6 \\
\pm 1.6\end{array}$ & $\begin{array}{l}76.8 \% \\
\pm 3.2\end{array}$ & $\begin{array}{l}63.1 \% \\
\pm 3.9\end{array}$ & $\begin{array}{l}89.5 \% \\
\pm 2.0\end{array}$ \\
\hline
\end{tabular}

a Numbers in brackets indicate patients also studied in Table 1

${ }^{b}$ Percent of desirable body weight, according to the middle of the weight range for subjects of medium frame, from the 1959 Metropolitan Life Insurance Co. Tables

c $\mathrm{I}=$ insulin treatment; $\mathrm{O}=$ oral agents; $\mathrm{D}=$ diet only

ADP concentrations in the test system. Increasing concentrations of ADP resulted in increased PSC curve-amplitudes, as shown in Figure 2. ADP $10 \mu \mathrm{mol} / \mathrm{l}$ was chosen because this concentration always induced irreversible aggregation in conventionally prepared PRP and was therefore assumed to provide maximal stimulation also in $\mathrm{Ca}^{++}$-deprived PRP. EDTA in the concentration used always inhibited ADP-induced aggregation but never produced variations in optical density of PRP by itself.

\section{Platelet Aggregation}

Patients. Seventeen normal controls and 30 diabetic patients were investigated, after obtaining informed consent. Of the diabetics, 10 had background retinopathy, 10 had maculopathy and 10 had proliferative retinopathy. Details are shown in Table 2, where information on the number of patients in each group studied for PSC is also given. Four patients were on $\alpha$-methyldopa medication. The severity of retinopathy was assessed as described above (Table 2).

Methods. Blood samples were obtained, and PRP and PPP prepared, as described. PRP $(500 \mu l)$ was heated to $37^{\circ} \mathrm{C}$ and stirred at $1,100 \mathrm{rpm}$. Fifty $\mu \mathrm{l}$ of ADP serial dilutions, giving final concentrations of $0.4,1.2,2.0$ and $10.0 \mu \mathrm{ml} / 1$, were added. Fifty $\mu \mathrm{l}$ of collagen (Worthington Biochem. Comp., Freehold, New Jersey) and $50 \mu \mathrm{l}$ ristocetin (H. Lundbeck \& Co., A/S Copenhagen) were used, giving final concentrations of $1 \mathrm{mg} / \mathrm{ml}$ and $2 \mathrm{mg} / \mathrm{ml}$ respectively. Aggregation tracings following the addition of ADP $10 \mu \mathrm{mol} / 1$, collagen and ristocetin were measured as \% light transmittance variations. Platelet sensitivity was determined by the lowest ADP concentration still able to induce irreversible aggregation.

Statistical Methods. The statistical evaluation of the results obtained was done by unpaired Student $t$ test. Non-parametric

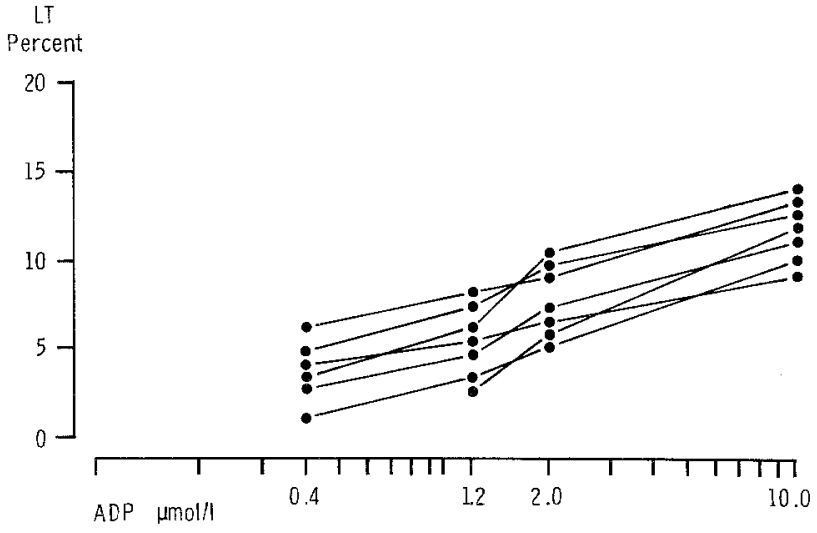

Fig. 2. Effect of ADP concentration on PSC curves amplitude. Platelet rich plasma was incubated with EDTA $7.6 \mathrm{mmol} / 1$ and warmed to $37^{\circ} \mathrm{C}$ in an aggregometer. The addition of increasing amounts of ADP produced a dose related increase of the PSC measurements. For details see text and Figure 1

analysis ( $\mathrm{X}^{2}$ test) was used for the ADP threshold results. All the results are expressed as mean $\pm \mathrm{SEM}$.

Reproducibility Studies. The mean coefficient of variation (CV) of PSC measurements within samples was $\pm 15.2 \%$, and $\pm 21.7 \%$ between samples obtained from the same subjects on different days. Conventional techniques had coefficients of variation (within samples) of $\pm 7.5 \%$ for LT variations induced by ADP $10 \mu \mathrm{mol} / 1$, $\pm 14.6 \%$ for collagen $1 \mathrm{mg} / \mathrm{ml}$, and $\pm 3.9 \%$ for ristocetin $2 \mathrm{mg} / \mathrm{ml}$. 


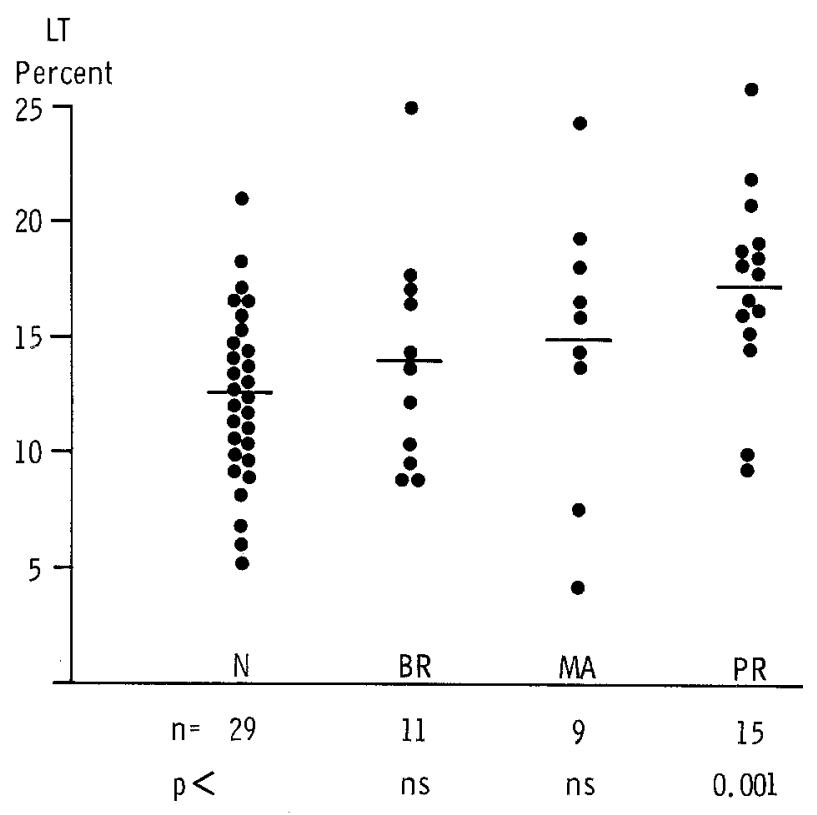

Fig. 3. PSC evaluation in platelets from normal and diabetic subjects. For details see text and Table 1. LT = Light Transmittance; $\mathrm{n}=$ number of patients. $\mathrm{N}=$ Normal controls; $\mathrm{BR}=$ Background Retinopathy. $\mathrm{MA}=$ Maculopathy; $\mathrm{PR}=$ Proliferative Retinopathy (From: Minerva Endocrinol (1979) 4: 169-170)

Table 3. ADP threshold in platelets from normal and diabetic subjects. ADP in serial dilutions was added to platelet rich plasma and the lower concentration still able to induce irreversible aggregation was noted. The table shows the number of subjects, expressed as a percentage of the total in each group, subdivided in accordance with the ADP threshold so assessed

\begin{tabular}{lllll}
\hline & \multicolumn{4}{l}{ ADP $\mu \mathrm{mol} / 1$} \\
\cline { 2 - 5 } & 0.4 & 1.2 & 2.0 & 10.0 \\
\hline $\begin{array}{l}\text { Controls } \\
\begin{array}{l}\text { Diabetics with } \\
\text { background retinopathy }\end{array}\end{array}$ & $5.9 \%$ & $5.9 \%$ & $41.2 \%$ & $47.0 \%$ \\
$\begin{array}{l}\text { Diabetics with } \\
\text { maculopathy }\end{array}$ & $10 \%$ & $20 \%$ & $40 \%$ & $30 \%$ \\
$\begin{array}{l}\text { Diabetics with } \\
\text { proliferative } \\
\text { retinopathy }\end{array}$ & $10 \%$ & $30 \%$ & $40 \%$ & $20 \%$ \\
\hline
\end{tabular}

\section{Results}

\section{Platelet Shape Change}

PSC assessment revealed a significant difference between platelets from diabetic patients $(15.6 \pm 1.0 \%)$ and controls $(12.6 \pm 0.7 \%)(p<0.02)$. Analysis of clinical details showed that this difference was mainly due to the group with proliferative retinopathy (17.3 $\pm 1.1 \%)(\mathrm{p}<0.001)$ (Table 1 and Fig. 3$)$.

In the control group, no correlation was found between PSC, age and sex. PSC was assessed at 2 hourly intervals for 24 hours in 4 insulin-dependent diabetics: no correlation was found between the measured values and food intake, insulin administration, and half-hourly blood glucose levels.

\section{Platelet Aggregation}

No quantitative differences in platelet aggregation induced by ADP (final concentration, $10 \mu \mathrm{mol} / \mathrm{l}$ ), collagen and ristocetin were found between controls and diabetic patients with different degrees of retinopathy (Table 2). A trend to incresed sensitivity to low $\mathrm{ADP}$ concentrations was found in platelets from patients with proliferative retinopathy (Table 3), but this result was not significant.

\section{Discussion}

Increased in vitro platelet aggregability $[1,2,3,4]$, enhanced platelet synthesis of pro-aggregating metabolites of arachidonic acid [5] and accelerated platelet turn-over in vivo $[8,9,10]$ have been reported in patients with diabetes. These findings are not uniformly accepted as some Authors have been unable to detect similar abnormalities $[11,12]$.

Platelet aggregation is a complex phenomenon and several phases have been described. The circulating platelets maintain their discoid shape by an energy requiring and $\mathrm{Ca}^{++}$-independent process $[13$, 14]. The initial reaction after exposure to ADP is shape change; the subsequent following events require calcium ions. Therefore, it is possible to study PSC independently from platelet aggregation if a chelating agent is added to PRP.

PSC studies were performed in order to establish whether some of the platelet abnormalities previously reported in diabetes are related to alterations in this early phase of platelet activation, especially as evidence has recently been found that blood coagulation is accelerated in the presence of platelets which have undergone the shape change [15]. A higher susceptibility of platelets to PSC inducing agents could contribute to the formation of microthrombi.

A pattern similar to that shown in Figure 1 has been described in rabbit platelets [16] and it was observed by electron microscopy that the increase in optical density is related to the spinyspherical rearrangement, while the slow decrease is caused by the recovery of the discoid shape. The measurement of LT variations should therefore estimate the mor- 
phological rearrangements occurring in the stimulated platelets.

PSC assessment in diabetic patients with proliferative retinopathy revealed values significantly higher than in normal controls. The underlying pathophysiological mechanism of this observation is at present unknown and further morphological and metabolic studies are required to elucidate this phenomenon. However, the apparent lack of correlation between BS variations and PSC in the 4 patients studied overnight excludes a direct influence of hyperglycaemia on this platelet mechanism.

Conventional aggregation studies in diabetics and controls showed a non-significant trend to increased sensitivity to ADP (Table 3) in platelets from patients with severe retinopathy. No differences were found between these groups when maximal stimulation was achieved by $A D P$, collagen and ristocetin.

These data disagree with some reports in the literature and this could reflect differences in the selection of patients (particularly in respect to other vascular complications), minor variations in the technique and in the numbers of subjects investigated. The results of this study, although not extended to a large population, suggest that abnormalities in platelet function are more often present in patients with proliferative retinopathy rather than in those with background lesions. Since the latter represent the initial manifestation of diabetic retinopathy, platelet alterations appear to parallel the progression of the disease. However, to determine the relevance of platelet abnormalities in diabetic retinopathy, longitudinal prospective studies of diabetic patients are required.

Acknowledgernents. We would like to acknowledge the technical help of Mr. Angus McCraw.

This work was supported by the Scientific Section of the British Diabetic Association and by a grant from the Fondazione per lo Studio, la Prevenzione e la Terapia della Retinopatia Diabetica (Turin, Italy).

\section{References}

1. Heath H, Bridgen WD, Canever J V, Pollock J, Hunter P R, Kelsey J, Bloom A (1971) Platelet adhesiveness and aggregation in relation to diabetic retinopathy. Diabetologia $7: 308-311$

2. Leone G, Bizzi B, Accorrà F, Boni P (1974) Functional aspects of platelets in diabetes mellitus. In: Caprino L, Rossi
FC (eds) Platelet aggregation and drugs. Academic Press, New York, p 49-61

3. Bensoussan D, Levy-Toledano S L, Passa P, Caen J, Canivet J (1975) Platelet hyperaggregation and increased level of von Willebrand factor in diabetics with retinopathy. Diabetologia $11: 307-312$

4. Colwell J A, Halushka PV, Sarji K, Levin J, Sagel J, Nair RMG (1976) Altered platelet function in diabetes mellitus. Diabetes 25:826-831

5. Halushka PV, Lurie D, Colwell J A (1977) Increased synthesis of prostaglandin-E-like material by platelets from patients with diabetes mellitus. N Engl J Med 297:1306-1310

6. Kohner EM (1978) The evolution and natural history of diabetic retinopathy. In: Kohner EM (ed) Diabetic retinopathy. Int. Opthalm. Clin. Little Brown \& Co., Boston, p $1-16$

7. McMillan DC, Oliver MR (1965) The initial changes in platelet morphology following the addition of adenosine diphosphate. J Atheroscl Res 5:440-444

8. Ferguson JC, Mackay N, Philip J AD, Sumner D J (1975) Determination of platelet and fibrinogen half-life with ${ }^{75}$ Seleniomethionine: studies in normal and in diabetic subjects. Clin Sci Mol Med 49:115-120

9. Bern MM (1978) Platelet function in diabetes mellitus. Diabetes $27: 342-350$

10. Burrows A W, Chavin SI, Hockaday TD R (1978) Plasma $\beta$ thromboglobulin concentrations in diabetes mellitus. Lancet I: 235-237

11. Petersen H D, Gormsen J (1978) Platelet aggregation in diabetes mellitus. Acta Med Scand 203:125-130

12. Campbell IW, Dawes J, Fraser D M, Pepper D S, Clarke BF, Duncan LJ, Cash J D (1977) Plasma beta-thromboglobulin in diabetes mellitus. Diabetes 26:1175-1177

13. Karpatkin S, Langer RM (1968) Biochemical energetics of stimulated platelet plug formation. Effect of thrombin, adenosine diphosphate and epinephrine on intra and extracellular adenine nucleotide kinetics. J Clin Invest 47:2158-2168

14. Zucker MB, Zaccardi JB (1964) Platelet shape change induced by adenosine diphosphate and prevented by adenosine monophosphate. Fed Proc 23:299

15. Ehrman M, Toth E, Frajmovic M (1976) A platelet procoagulant activity associated with platelet shape change. J Lab Clin Med 87:909-912

16. Born GVR, Dearnley R, Foulks J G, Sharp D E (1978) Quantification of the morphological reaction of platelets to aggregating agents and of its reversal by aggregation inhibitors. J Physiol (Lond) 280:193-212

Received: July 3, 1979,

and in revised form: December 12, 1979

\author{
Dr. M. Porta \\ Department of Medicine \\ Hammersmith Hospital \\ Ducane Road \\ London W12 OHS \\ England
}

